\title{
PENGUATAN USAHA PERIKANAN DI KAMPUNG LAUK
}

\author{
Yuyus Yudistria \\ yuyus.yudistria@ekuitas.ac.id \\ Deddy Rusyandi \\ derusy@gmail.com
}

\section{SEKOLAH TINGGI ILMU EKONOMI EKUITAS}

\begin{abstract}
ABSTRAK
Kampung Lauk di Desa Lampegan merupakan salah satu kampung yang terdaftar sebagai program 1000 kampung di Kabupaten Bandung. Di kampung Lauk sebagian pelaku usaha/anggota kelompok tingkat pendidikanya rendah, serta masih kurangnya pemahaman dalam usaha, manajemen pengelolaan dan rantai nilai dari usahanya. Jumlah kelompok lauk belum terlalu banyak, masing-masing kelompok terdiri sekitar 6 orang yang menjalankan usaha ini. Inilah tujuan kami melakukan pengabdian di daerah ini untuk meningkatkan kualitas SDM dengan peningkatan pemahaman usaha serta rantai nilai. Metode pelatihan yang dilakukan adalah dengan cara on the spot di lokasi tempat beradanya kegiatan usaha dilakukan serta di tindak lanjuti dengan advokasi berupa konsultasi perihal perkembangan penerapan setelah dilakukannya kegiatan pelatihan. Pelatihan penguatan kualitas SDM dan rantai nilai pada kelompok usaha berdasarkan pada pelakasanaan pelatihan pelaku usaha kelompok kampung lauk: memiliki rencana usaha kedepan, Memiliki rencana dan perhitungan usaha, Memiliki pengelolaan keuangan (manajemen keuangan yang lebih baik) atau pencatatan keuangan. Mengetahui dan menerapkan pengembangan usaha di tinjau dari rantai nilai (bahan baku, pakan, dan pemasaran).
\end{abstract}

Kata kunci: Penguatan Usaha, Rantai Nilai.

\section{PENDAHULUAN}

Kampung Lauk di Desa Lampegan merupakan salah satu kampung yang terdaftar sebagai program 1000 kampung di Kabupaten Bandung. Di kampung Lauk sebagian pelaku usaha/anggota kelompok tingkat pendidikanya rendah, serta masih kurangnya pemahaman dalam usaha, manajemen pengelolaan dan rantai nilai dari usahanya. Dengan rendahnya pemahaman kewirausahaan dan minimnya pemahaman tentang rantai nilai sehingga kegiatan usaha yang dilakukan masih sebatas alakadarnya/tradisional.

Jumlah kelompok lauk belum terlalu banyak, masing-masing kelompok terdiri sekitar 6 orang yang menjalankan usaha ini. Kampung Ikan/Lauk berada di Kecamatan Ibun, khususnya Desa Lampegan. Kecamatan Ibun memiliki luas wilayah 4.442 Hektar, sedangkan luas wilayah Desa Neglasari yaitu 99 Hektar, sehingga seluruh luas desa yang menjadi Kampung Ikan/Lauk merupakan 2,23\% dari luas wilayah Kecamatan Ibun. Berdasarkan jumlah penduduknya, Kecamatan Ibun memiliki 
total jumlah penduduk 83.903, sedangkan jumlah penduduk Desa Lampegan yaitu 7.220, sehingga total jumlah penduduk yang tinggal di desa yang termasuk dalam Kampung Ikan/Lauk merupakan $8,6 \%$ dari jumlah penduduk Kecamatan Ibun.

Berdasarkan pengamatan tim pada lapangan, upaya penguatan kualitas SDM dan rantai nilai pada kelompok usaha dinilai mampu meningkatkan produksi lebih banyak dengan tetap menjaga kualitas. Diharapkan juga kelompok usaha ini akan semakin berkembang, sehingga akan lebih dikenal oleh konsumen atau wisatawan yang berkunjung ke kampung lauk. Dengan demikian, agar tercipta penguatan kualitas SDM dan rantai nilai pada kelompok usaha kampung lauk maka dilakukan pelatihan yang fokus pada dua bidang tersebut.

\section{METODOLOGI PELAKSANAAN}

Metodologi pelatihan yang dilakukan adalah dengan cara on the spot di lokasi tempat beradanya kegiatan usaha dilakukan serta di tindaklanjuti dengan advokasi berupa konsultasi perihal perkembangan penerapan setelah dilakukannya kegiatan pelatihan. Mayoritas saat ini pelaku usaha pernah mengikuti pelatihan dari berbagai instansi namun demikian masih banyak pelaku usaha yang mengeluh tentang metode pelaksanaan Pelatihan salah satunya pelaksanaan yang singkat, tidak ada kelanjutan dari pelatihan serta bentuk pelatihan yang tidak sesuai dengan kebutuhan pelaku usaha (Tambunan, 2012).

Pengembangan UMKM masih diperlukan pemacu salah satunya dalam peningkatan sumber daya manusia. Masalah lain yang dihadapi UKM, yaitu adanya masalah pada sumber daya manusia. Clarke (2015) Salah satu usaha dalam meningkatkan kualitas SDM adalah dalam kehidupan perekonomian didasarkan pada mekanisme pasar. Jean Batiste Say menjadi pendukung pemikiran Adam Smith, memperbaiki sistem Adam Smith dengan cara yang lebih sistematis serta logis. Karya Say dikenal sebagai Hukum Say (Say's Law) yaitu supply creates its oven demand tiap penawaran akan menciptakan permintaanya sendiri, Pujiati (2011) dalam kajiannya menemukan bahwa pelatihan memiliki arti penting dalam pengembangan ekonomi. Memberikan pelatihan langsung kepada industri kecil dianggap merupakan satusatunya cara yang paling efektif.

Tujuan yang hendak dicapai dari setiap supply chain adalah untuk memaksimalkan nilai yang dihasilkan secara keseluruhan (Chopra, 2016). Supply chain yang terintegrasi akan meningkatkan keseluruhan nilai yang dihasilkan oleh rantai nilai tersebut. Hubungan supply chain memiliki arti sebagian elemen dalam rangkaian Supply Chain Management (SCM) berada dalam lingkup yang kompak serta memiliki ketergantungan. Suatu usaha jika menerapkan Praktik SCM, maka akan menguntungkan serta berdampak positif, sehingga elemen yang terlibat dalam usaha akan berkaitan satu sama lain dari hulu sampai hilir

Metode pelaksanaan dalam kegiatan ini adalah pelatihan terbagi ke dalam beberapa tahapan seperti:

\section{Tahapan Persiapan:}

- Informasi Pendidikan Pelaku Usaha

- Pengetahuan usaha Perikanan

- Pengetahuan manajemen Usaha

- Informasi bahan baku bibit

- Informasi pakan

- Keberlanjutan ketersediaan bibit dan pakan

- Informasi pengelolaan usaha

- Informasi Pemasaran

Tahap Pelaksanaan

- Sosialisasi program Pelatihan

- Pelatihan kewirausahaan (Business Plan) Pelatihan ini peserta diharapkan memiliki rencana usaha kedepan

- Pelatihan Perhitungan biaya produksi Peserta diharapkan memiliki rencana dan perhitungan usaha 
- Pelatihan pengembangan usaha di tinjau dari rantai nilai (bahan baku, pakan, dan pemasaran)

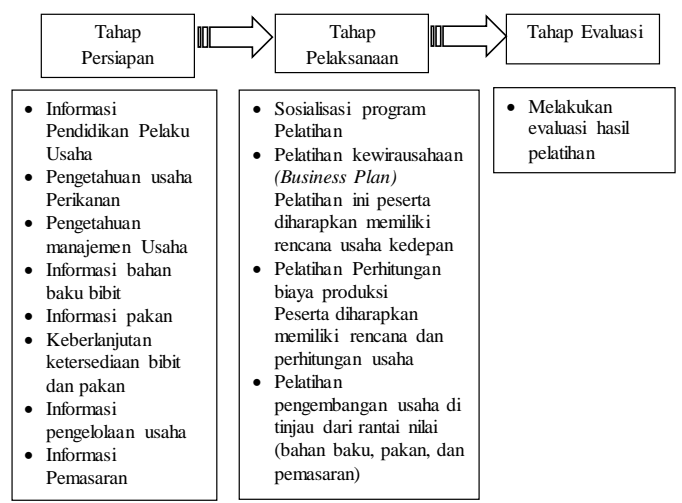

Gambar 1. Tahapan Pelaksanaan Kegiatan.

\section{HASIL DAN LUARAN}

Tantangan yang dihadapi dalam memperkuat struktur ekonomi daerah dirasakan cukup berat. Salah satu program dalam pembinaan pelaku UMKM harus lebih diarahkan dalam meningkatkan kemampuan usahanya. Disadari pula bahwa pengembangan UMKM dalam menghadapi kendala-kendala ciri khas UMKM yaitu kemampuan, keterampilan, keahlian, manajemen SDM, kewirausahaan, pemasaran serta keuangan.

Masih lemahnya dalam manajerial dan sumberdaya manusia berdampak pada ketidakmampuannya pelaku UMKM dalam menjalankan usahanya. Sehingga masalah dasar yang dihadapi UMKM, yaitu lemahnya memperoleh peluang pasar dan memperluas pangsa pasar; kelemahan permodalan serta terbatasnya memperoleh jalur sumber permodalan; Bidang organisasi dan manajemen SDM; terbatasnya jaringan usaha antara pengusaha kecil; iklim usaha kurang kondusif, sehingga persaingan yang dilakukan antara UMKM saling mematikan; pembinaan masih kurang terpadu serta kurangnya kepedulian masyarakat terhadap usaha kecil.

Sesuai dengan Undang-Undang No 20 tahun 2008 pasal 4 menyebutkan bahwa prinsip pemberdayaan usaha Usaha Mikro, Kecil, dan Menengah: a. Penumbuhan kemandirian, kebersamaan, dan kewirausahaan UMKM untuk berkarya dengan prakarsa sendiri;

b. Perwujudan kebijakan publik yang transparan, akuntabel, dan berkeadilan;

c. Pengembangan usaha berbasis potensi daerah dan berorientasi pasar sesuai dengan kompetensi UMKM;

d. Peningkatan daya saing UMKM; dan

e. Penyelenggaraan perencanaan, pelaksanaan, dan pengendalian secara terpadu.

Hasil dari pelaksanaan Pelatihan yang telah dilakukan dihasilkan seperti yang terdapat dalam tabel berikut:

Tabel. 1. Kondisi Mitra Sebelum dan

Setelah Pelaksanaan Pelatihan

\begin{tabular}{|c|c|c|}
\hline Pelatihan & $\begin{array}{l}\text { Kondisi } \\
\text { Sebelum }\end{array}$ & $\begin{array}{c}\text { Kondisi } \\
\text { Setelah } \\
\text { pelatihan }\end{array}$ \\
\hline $\begin{array}{l}\text { Business } \\
\text { Plan }\end{array}$ & $\begin{array}{l}\text { Pelaku } \\
\text { usaha belum } \\
\text { mengetahui } \\
\text { tentang } \\
\text { perencanaan } \\
\text { berusaha }\end{array}$ & $\begin{array}{l}\text { Pelaku } \\
\text { usaha } \\
\text { memahami } \\
\text { perencanaan } \\
\text { / target } \\
\text { usahannya } \\
\text { kedepan } \\
\text { baik dalam } \\
\text { produksi } \\
\text { maupun } \\
\text { pengemban } \\
\text { gan usaha }\end{array}$ \\
\hline $\begin{array}{l}\text { Perencanaa } \\
\text { n dan } \\
\text { Perhitunga } \\
\text { n Biaya } \\
\text { Produksi }\end{array}$ & $\begin{array}{l}\text { Pelaku } \\
\text { usaha tidak } \\
\text { memiliki } \\
\text { perhitungan } \\
\text { biaya } \\
\text { produksi }\end{array}$ & $\begin{array}{l}\text { Pelaku } \\
\text { usaha } \\
\text { menjadi } \\
\text { tahu, } \\
\text { memahami } \\
\text { dan belajar } \\
\text { dalam } \\
\text { perhitungan } \\
\text { usaha } \\
\text { terutama } \\
\text { dalam biaya } \\
\text { produksi. }\end{array}$ \\
\hline & $\begin{array}{l}\text { Pelaku } \\
\text { usaha } \\
\text { selama ini }\end{array}$ & $\begin{array}{l}\text { Peserta } \\
\text { memahami } \\
\text { dan }\end{array}$ \\
\hline
\end{tabular}




\begin{tabular}{|c|c|c|}
\hline & $\begin{array}{l}\text { mencampuk } \\
\text { an uang } \\
\text { pribadi/kelu } \\
\text { arga dengan } \\
\text { keuangan } \\
\text { usaha }\end{array}$ & $\begin{array}{l}\text { memisahka } \\
\mathrm{n} \text { antara } \\
\text { keuangan } \\
\text { sendiri/kelu } \\
\text { arga dengan } \\
\text { keuangan } \\
\text { usahanya. } \\
\text { Serta pelaku } \\
\text { usaha } \\
\text { memiliki } \\
\text { pencatatan } \\
\text { keuangan }\end{array}$ \\
\hline \multirow[t]{3}{*}{$\begin{array}{l}\text { Pengemban } \\
\text { gan Usaha } \\
\text { dari aspek } \\
\text { rantai nilai }\end{array}$} & $\begin{array}{l}\text { Peserta } \\
\text { belum } \\
\text { mengetahui } \\
\text { memahami } \\
\text { asal bahan } \\
\text { baku } \\
\text { keberlanjuta } \\
\text { n bahan } \\
\text { baku dan } \\
\text { cara } \\
\text { menciptaka } \\
\text { n } \\
\text { pembibitan }\end{array}$ & $\begin{array}{l}\text { Peserta } \\
\text { mengetahui } \\
\text { bagaimana } \\
\text { caranya } \\
\text { adanya } \\
\text { keberlanjuta } \\
\text { n bahan } \\
\text { baku, } \\
\text { pengemban } \\
\text { gan dan } \\
\text { bahan baku } \\
\text { (pembibitan } \\
\text { ) }\end{array}$ \\
\hline & $\begin{array}{l}\text { Peserta } \\
\text { belum } \\
\text { mengetahui } \\
\text { bagaimana } \\
\text { cara } \\
\text { kelangkaan } \\
\text { pakan }\end{array}$ & $\begin{array}{l}\text { Peserta } \\
\text { mengetahui } \\
\text { bagaimana } \\
\text { caranya } \\
\text { dalam } \\
\text { menghadapi } \\
\text { masalah } \\
\text { dalam } \\
\text { pakan. } \\
\text { (pelaku } \\
\text { usaha dapat } \\
\text { membuat } \\
\text { pakan } \\
\text { sendiri } \\
\text { dengan } \\
\text { bahan baku } \\
\text { bersumber } \\
\text { dari sumber } \\
\text { daya } \\
\text { sekitar) }\end{array}$ \\
\hline & $\begin{array}{l}\text { Peserta } \\
\text { mengalami } \\
\text { permasalaha } \\
\text { n dalam hal } \\
\text { pemasaran }\end{array}$ & $\begin{array}{l}\text { Peserta } \\
\text { mengetahui } \\
\text { cara dan } \\
\text { potensi } \\
\text { pasar }\end{array}$ \\
\hline
\end{tabular}

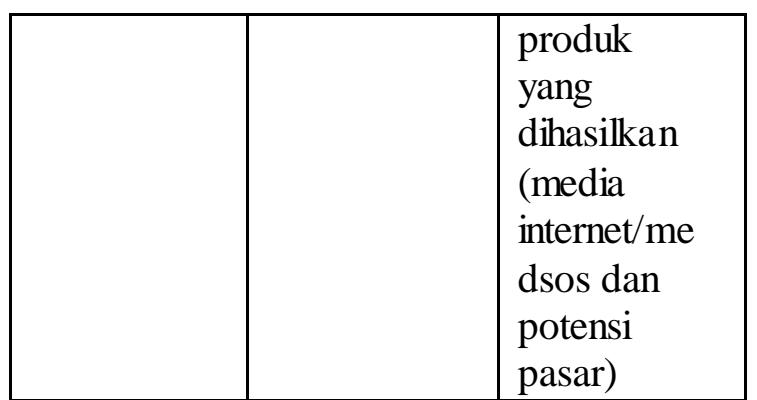

Sumber: Hasil evaluasi pelaksanaan kegiatan (2020)

Berdasarkan pelakasanaan pelatihan tersebut pelaku usaha kelompok kampung lauk dihasilkan:

1. Pelaku usaha memiliki rencana usaha kedepan dengan mengetahui unsur - unsur yang harus ada dalam perencanaan bisnis, menggali peluang usaha dan memahami beberapa proses pengembangan seperti:

A. Unsur dalam perencanaan bisnis
a) Ringkasan Eksekutif
b) Profil Usaha
c) Strategi Usaha
d) Produk dan Jasa
e) Strategi Pemasaran
f) Analisis Pesaing
g) Spesifikasi Organisasi \& Manajemen
h) Aspek Legal
i) Rencana Operasional
j) Data Finansial
k) Proposal/Usulan Pinjaman
l) Jadwal Operasional
m) Risiko Bisnis

B. Mecari peluang usaha:
a) Kerjasama
b) Optimis
c) Mendengarkan saran
d) Terbuka
e) Kreatif

C. Proses pengembangan
a) Ide,
b) perencanaan,
c) Uji pasar,
d) Diversifikasi Pemasaran dan
e) Diversifikasi hasil produksi 
2. Memiliki perencanaan perhitungan usaha antara lain:

a) Modal yang dimiliki,

b) Sumber dan perencanaan penggunaan dana

c) Proyeksi keuangan, pendapatan, saldo. malik modal

Tabel. 2. Perencanaan Keuangan

\begin{tabular}{|c|c|}
\hline Item & Uraian \\
\hline Nama usaha & $\begin{array}{l}\text { Budidaya ikan di Kampung } \\
\text { Lauk }\end{array}$ \\
\hline Deskripsi usaha & $\begin{array}{l}\text { Pembesaran ikan } \\
\text { menggunakan kolam }\end{array}$ \\
\hline Produk & $\begin{array}{l}\text { Produk ikan mas, nila, lele, } \\
\text { dan ikan hias }\end{array}$ \\
\hline - Harga & Rp 14.000.000, 00 \\
\hline \begin{tabular}{|l|} 
pemasaran \\
Area
\end{tabular} & $\begin{array}{l}\text { Pemasaran meliputi kota- } \\
\text { kota di Bandung Raya }\end{array}$ \\
\hline & $\begin{array}{l}\text { Distributor datang } \\
\text { langsung ke lokasi } \\
\text { budidaya. Distributor } \\
\text { kemudian akan } \\
\text { memasarkan ikan mas ke } \\
\text { berbagai daerah. }\end{array}$ \\
\hline \begin{tabular}{|l|} 
Aspek \\
produksi
\end{tabular} & \\
\hline $\begin{array}{l}-\quad \text { Masa } \\
\text { pananaman } \\
\text { benih }\end{array}$ & 4 bulan \\
\hline 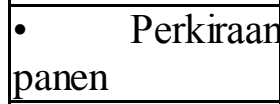 & $\begin{array}{l}\text { Minimal panen } 3 \text { kali per } \\
\text { tahun. }\end{array}$ \\
\hline - Skala usaha & $\begin{array}{l}4 \text { kolam. Satu kolam } \\
\text { berukuran } 7 \text { x7 meter } \\
\text { persegi. }\end{array}$ \\
\hline - Bibit & $\begin{array}{l}\text { Satu kolam membutuhkan } \\
100 \mathrm{~kg} \text { benih/ masa panen. } \\
\text { Harga bibir berkisar antara } \\
\text { Rp } 15.000,00 \text { s.d Rp } \\
25.000,00 \text { per kilogram. }\end{array}$ \\
\hline - Pakan & $\begin{array}{l}\text { Pakan pelet } 2.5 \text { ton per } \\
\text { petak per masa panen. } \\
\text { Harga pakan berkisar } \\
\text { antara Rp } 200.000,00 \text { s.d } \\
\text { Rp } 400.000,00 \text { per } 50 \\
\text { kilogram }\end{array}$ \\
\hline & $\begin{array}{l}\text { Bibit ikan ditebar di } \\
\text { kolam. Dengan pemberian } \\
\text { pakan dan perawatan } \\
\text { kolam secara rutin. }\end{array}$ \\
\hline
\end{tabular}

\begin{tabular}{|c|c|}
\hline - Teknologi & Tidak ada. \\
\hline & $\begin{array}{l}\text { Untuk } 1 \text { kolam dibutuhkan } \\
1 \text { orang tenaga kerja yang } \\
\text { bertugas merawat kolam } \\
\text { dan memberi pakan. }\end{array}$ \\
\hline Resiko & $\begin{array}{l}\text { Resiko, virus, dan air } \\
\text { (keruh/kotor) }\end{array}$ \\
\hline - Jangka waktu & 3 tahun \\
\hline \begin{tabular}{|l} 
Komposis \\
modal
\end{tabular} & $\begin{array}{l}30: 70 \text { modal sendiri } \\
\text { terhadap pinjaman }\end{array}$ \\
\hline - $\quad$ Pendapatan & Tahun 1-3Rp \\
\hline per tahun & $21.000 .000,00$ \\
\hline Pengeluaran & Tahun 1-3 Rp \\
\hline per tahun & $19.000 .000,00$ \\
\hline $\begin{array}{l}\text { Break event } \\
\text { quantity }\end{array}$ & $17 \mathrm{Kg}$ \\
\hline $\begin{array}{l}\text { Break event } \\
\text { sales }\end{array}$ & Rp 24. 000.000, 00 \\
\hline - NPV & $\operatorname{Rp} 7.000 .000,00$ \\
\hline - IRR & $94 \%$ selama 3 tahun \\
\hline \begin{tabular}{|ll} 
modal & Kembali \\
\end{tabular} & 1,4 tahun \\
\hline
\end{tabular}

Sumber: Data Olah, 2020

3. Mengetahui dan menerapkan pengembangan usaha di tinjau dari rantai nilai (bahan baku, pakan, dan pemasaran), sehingga pelaku usaha Memiliki daftar distributor dan supplier bahan baku dan pakan serta konsumen. Selain itu pelaku usaha memahami dalam aspek pemasaran seperti:

Cara menganalisis pasar

a) Target pasar atau sasaran pasar,

b) Kebutuhan konsumen,

c) Potensi penjualan,

d) Perkiraan yang akan dicapai.

Strategi pemasaran

a) Perencanaan pemasaran

b) Perbandingan produk yang terdapat di pasaran

c) Lokasi pemasaran,

d) Distribusi dan jaringan usaha,

e) Penjualan,

f) Harga,

g) Promosi, 


\section{KESIMPULAN}

Berdasarkan hasil pelaksanaan kegiatan pelatihan penguatan kualitas SDM dan rantai nilai pada kelompok usaha, memiliki dampak positif terhadap kelompok usaha tersebut: dimana kelompok usaha tersebut sekitar $95 \%$ memiliki pemahaman tentang usaha, memiliki rencana usaha, memiliki rencana pengembangan dan perhitungan usaha, Memiliki pengelolaan keuangan (manajemen keuangan yang lebih baik) atau pencatatan keuangan. Serta kelompok usaha tersebut telah mampu menerapkan pengembangan usaha di tinjau dari rantai nilai (bahan baku, pakan, dan pemasaran).

Saran kedepannya perlu ada kegiatan pelatihan yang bersifat penggunaan teknologi terutama untuk pembuatan pakan ikan.

\section{DAFTAR PUSTAKA}

Pujiati, A. (2011). Menuju Pemikiran Ekonomi Ideal: Tinjauan Filosofis Dan Empiris. Fokus Ekonomi (FE), Vol. 10, No. 2.

Chopra, Sunil and Meindl, (2016), Supply Chain Management: Strategy, Planning and Operating, Prenticehall.

Clark, D. (2015). Financing of Education in Indonesia, Asian. Development Bank Comparative Education Reset Center The University of Hongkong.

Tambunan, T. (2012) Usaha Mikro Kecil dan Menengah di Indonesia : Isu-isu Penting. Jakarta: LP3ES.

Undang-Undang No 20 tahun 2008 Tentang Usaha Mikro, Kecil, dan Menengah. 